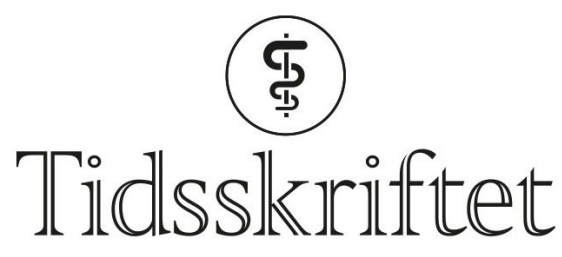

DEN NORSKE LEGEFORENING

\title{
Jobben som velges bort
}

REPORTASJE

LISA DAHLBAK JACOBSEN

E-post: Lisa.Dahlbak.Jacobsen@tidsskriftet.no Tidsskriftet

Den en gang så friske, fertile og vitale fastlegeordningen er omgjort til en 19 år eldre ordning med tilnavn krise. Og i en ordning i krise er det vanskelig å få folk til å jobbe.

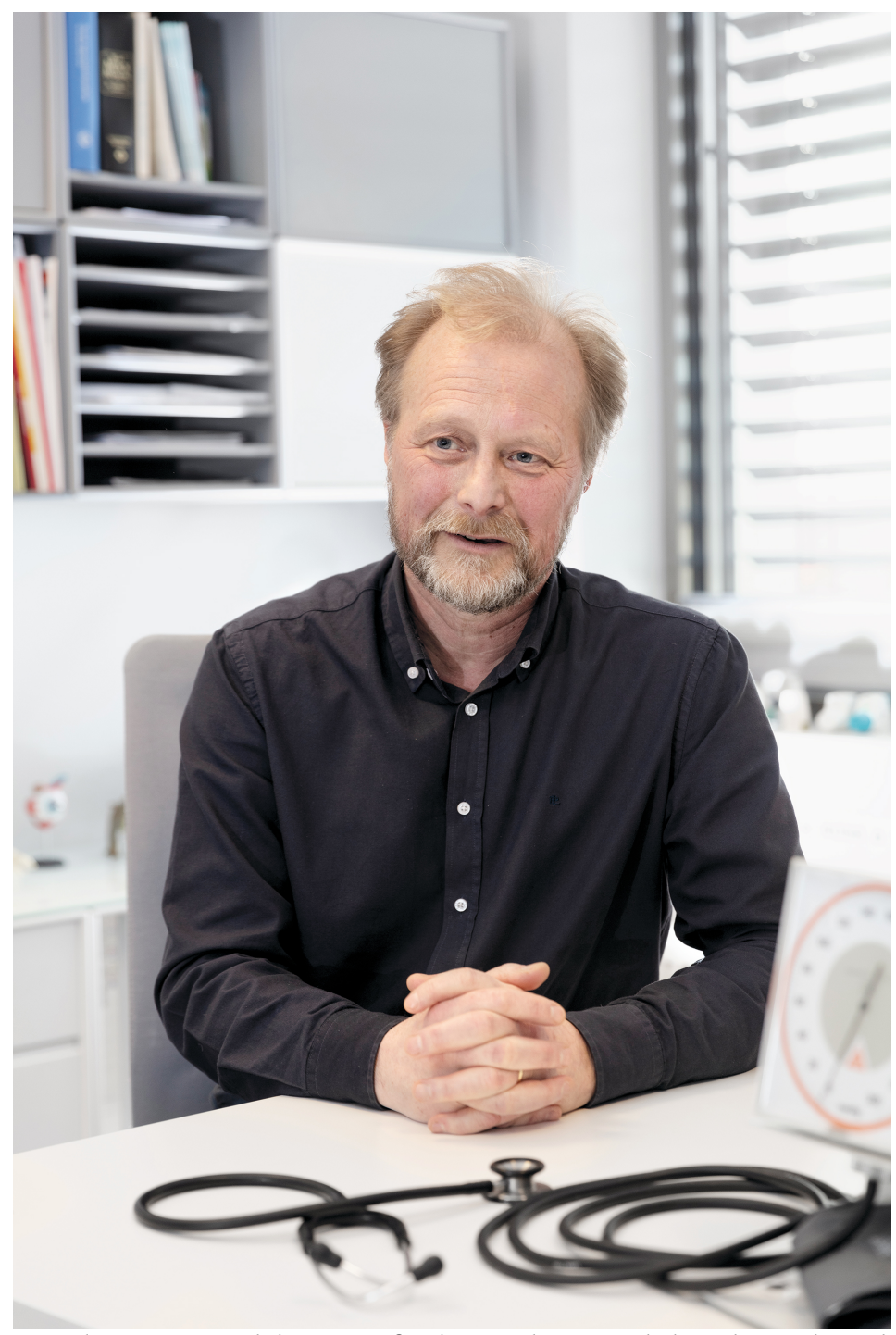

Per Olav Hognestad drev egen fastlegepraksis i Fredrikstad, men la ned og begynte som allmennspesialist hos Volvat. - En veloverveid beslutning, sier han. Foto: Christian Tunge 
Det var veldig bra, og veldig gøy til å begynne med, sier Per Olav Hognestad, spesialist $\mathrm{i}$ allmennmedisin. - Vi var tre kollegaer som startet opp et fastlegekontor sammen i Fredrikstad sentrum. Det var interessant med alle oppgavene vi skulle administrere. Vi måtte være «altmuligmenn» og skifte alt fra lyspærer til spiraler, ler han.

Hognestad og kollegaene startet Brygga legekontor i 1998 og ble deretter innlemmet i fastlegeordningen i 2001.

- De første årene i fastlegeordningen gikk bra. Men etter hvert forandret premissene seg gradvis. Til tross for uendret listelengde, endret arbeidsmåten seg radikalt i løpet av de 15 årene vi holdt det gående.

Administrativ byrde og lite faglig miljø er hovedargumentene for å velge bort allmennmedisin. Det viser den nye studien fra Legeforskningsinstituttet som nå er publisert i Tidsskriftet.

- Likevel finner vi at det er flere årsaker som er viktige når leger vurderer allmennmedisin. Det tolker vi dithen at bildet er sammensatt. For mange leger er det en kombinasjon av mange årsaker som gjør at allmennmedisin velges vekk når yrkesretningen stakes ut, forklarer førsteforfatter av den nye studien Cecilie Normann Birkeli, ph.d.-kandidat og rådgiver ved Legeforskningsinstituttet.

Store varsellamper har blinket og man har alarmert politikere og helsemyndigheter i mange år. Altfor mange går ut av ordningen, og altfor få kommer inn. Med all den negative oppmerksomheten er det ikke rart at noen velger seg bort, slutter eller ikke engang vurderer å arbeide i et «synkende skip». Men de fleste leger i Norge har likevel et hjerte for ordningens intensjon.

- Vi ble svarteper. Fastlegene overtok alle oppgaver og problemstillinger ingen andre hadde en løsning på. Jevnlig $ø$ kte antall arbeidstimer. Fra 40 til 50 til 60 timer i uken. Vi arbeidet mer og mer gratis om kvelden. Det kan ikke faktureres noe sted, sier Hognestad.

- Da samhandlingsreformen kom i 2012, sa en kollega av meg: «Sykehuset ‘sammer' og vi 'handler'». Det ble innført mange kanaler inn til fastlegene uten tilføring av ressurser. Intensjonene bak reformen er jo gode. Men etter min mening endte den med å fungere som en innsparingsmulighet for sykehusene på bekostning av ressurssterke, kreative og arbeidsvillige fastleger.

\section{Veloverveid beslutning}

- Jeg brukte mange år på å ta beslutningen om å tre ut av fastlegeordningen. Selvfølgelig er det sammensatt, men hovedårsaken var utviklingen av fastlegerollen i løpet av de siste årene. Jeg vurderte flere alternativer, men liker allmennmedisin aller best. Da tilbudet om å begynne i Volvat i Fredrikstad kom, takket jeg ja.

Han forteller at det ikke var godt å oppleve fastlegeordningen som et langsomt synkende skip - som han hoppet av i tide.

- Redningsarbeidet går for langsomt. Det trengs mer kreativitet og handlekraft i endringsarbeidet.

Hognestad forteller at det private tverrfaglige senteret har en annen måte å arbeide på.

- Vi setter av mye tid til hver pasient. Til tross for at det koster mer for pasientene, er de veldig fornøyde. Det gir meg stor tilfredsstillelse å ha god tid sammen med pasientene. Allmennleger liker jo pasientkontakt. Vi liker ikke urimelig mye tid i møter med Nav og liknende.

Han ser likevel utfordringene med at ikke alle har råd til å gå til Volvat.

- Vi er et supplement til det offentlige. De fleste trenger ikke bruke legen sin så ofte. Flere sier de aldri har møtt fastlegen sin. Mange bruker meg eller andre leger i Volvat som sin faste lege. Noen fra min tidligere fastlegepraksis, som har brukt meg i 15-20 år, har valgt å 
følge meg over til Volvat. Tilgjengelighet og time på dagen teller mye.

Hognestad har lave forventninger til helseminister Bent Høies handlingsplan for fastlegeordningen. Den skulle opprinnelig legges frem til påske, men er på grunn av unntakstilstand og covid-19 trolig ikke prioritert med det første.Allmennmedisineren mener det trengs en real omstrukturering og tilføring av ressurser.

- Man må ivareta de etablerte fastlegene og samtidig få inn flere leger, slik at mer av tiden kan brukes med pasientene. På den måten får man unge leger med familie til å ønske seg inn i en slik jobb. Og det må skje raskt!

Han påpeker at allmennmedisin er en flott jobb når man kan skape sin egen arbeidsplass og arbeide selvstendig.

- For meg var det utrolig givende å bygge opp praksisen sammen med gode kolleger og medarbeidere og skape min egen hverdag. Fastlegekontoret var den beste arbeidsplassen jeg noensinne har hatt, sier han og legger til:

- De første årene.

\section{Hun vi trenger}

Fastlege-Norge hadde egentlig trengt en som Marte Skogen Evje - en ung kvinnelig lege som identifiserer seg mer med allmennmedisin enn en sykehustilværelse. Men hun valgte altså bort allmennmedisinen. Hun kan krysse av på flere av årsaksfaktorene som Legeforskningsinstituttet spurte om i sin undersøkelse.

I distriktsturnus var hun i Ås, hvor hun fikk prøvd seg på helsestasjon, sykehjem og legevakt.

- Jeg likte godt distriktsturnusen, med god veiledning og en flott kommuneoverlege. Jeg fikk et realistisk inntrykk av allmennlegetilværelsen og arbeidshverdagen som selvstendig næringsdrivende, forteller Evje, og utdyper:

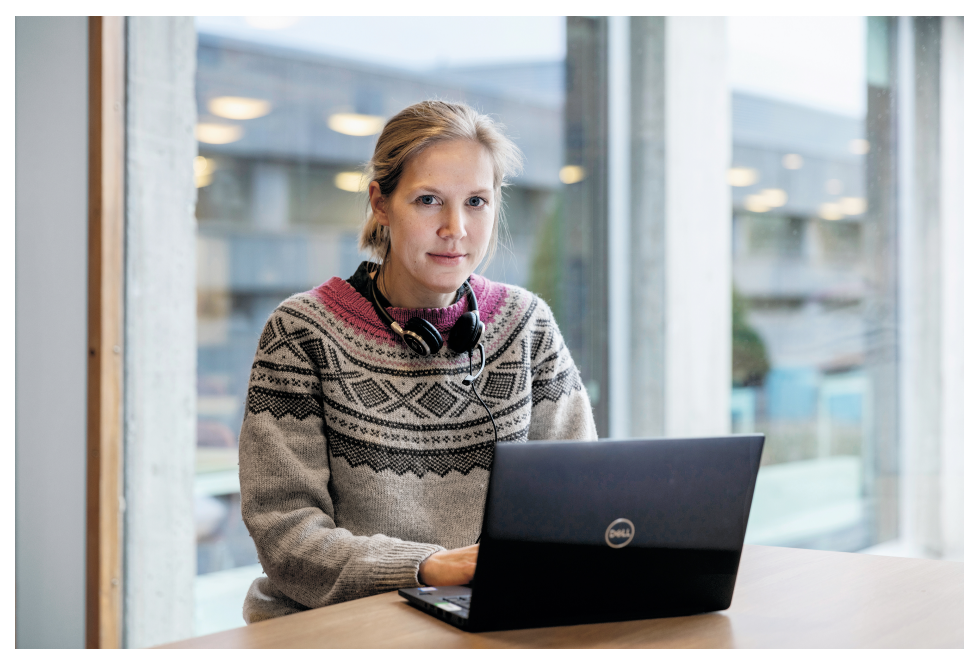

Marte Skogen Evje valgte seg Giftinformasjonen ved Folkehelseinstituttet som arbeidsplass, men vurderte også allmennmedisin. Foto: Christian Tunge

- Min veileder hadde mye administrativt arbeid. Han hadde arbeidet i mange år og var svært dreven og effektiv, men var ærlig om at arbeidshverdagen hadde endret seg mye de siste årene. Jeg gjorde meg noen refleksjoner, særlig da jeg underveis i turnustiden fikk mitt første barn.

Mens Evje fullførte turnus, hadde hun bestemt seg for retningen videre. Hun fikk god støtte i beslutningen av kommuneoverlegen.

- Jeg søkte om et vikariat som rådgiver hos Giftinformasjonen ved Folkehelseinstituttet. Jeg var veldig fornøyd med å få jobben. Det er en kjempespennende jobb. Fagmiljøet er stort, og vi jobber på et samfunnsmedisinsk plan og mye med forebygging. Selv om jeg har forlatt klinisk arbeid, får jeg "pasientkontakt» gjennom telefonvaktene på Giftinformasjonen. Mange av dem som ringer, er i en vanskelig og sårbar situasjon. Dessuten jobber vi tett med 
sykehusleger og annet helsepersonell, forteller hun entusiastisk.

At jobben også passer med familielogistikken, er et stort pluss.

- Jeg får i pose og sekk: en faglig interessant jobb og en familievennlig arbeidshverdag. Jeg kunne ikke vært mer fornøyd, poengterer hun og anmerker at tilværelsen er veldig annerledes fra da hun fikk første barn i turnus.

- Arbeidstiden og arbeidspresset var ikke lett kompatibelt med småbarnstilværelsen. Det skjønte jeg ganske raskt.

- Hva skulle til for at du hadde gått i retning allmennmedisin og eventuelt en fastlegeavtale?

- Først må jeg bare si at jeg liker veldig godt helhetsperspektivet som fastlegeordningen er tuftet på. Vi som familie er Oslo-basert. Her er det ikke legemangel, og veien mot en egen hjemmel føltes derfor lang. Jeg er veldig tilhenger av tanken om at kommunene må inn i spesialiseringsopplegget, og en ny modell der man er ansatt i for eksempel kommunen. Man vil på den måten få fast lønn og et ordnet arbeidsforhold.

Hun er nøye med å påpeke fordelene det vil gi leger med lignende livssituasjon som hennes - gode pensjonsordninger, mulighet for sykedager og uttak av foreldrepermisjon.

- Jeg har alltid likt allmennmedisin, men slik det er nå, er det veldig mye mer enn pasientkonsultasjoner.

\section{Rekrutteringspotensial}

- Det er motiverende å jobbe med så mange dyktige kolleger, og det er fint med en arbeidshverdag der man hele tiden har mulighet til å diskutere fag og spille hverandre gode, påpeker Evje om jobben i Folkehelseinstituttet.

Cecilie Normann Birkeli forklarer at flere fastleger oppga små faglige nettverk og lite faglig miljø som grunn til å velge seg bort fra allmennmedisin. Når fastlegene nå i større grad enn tidligere skal følge opp pasienter med flere lidelser, er det viktig med mulighet for faglig oppdatering og lett tilgang på faglig fordypning.

- Når leger velger seg bort grunnet stor administrativ byrde, kan det også henge sammen med digitale systemer som ikke prater sammen, færre merkantilt ansatte og til dels vanskelig tilgang til kommunikasjon med spesialisthelsetjenesten, sier hun og legger til:

- Legene som hadde valgt seg bort fra allmennmedisin, pekte på mange faktorer. Bildet er mer sammensatt enn man tidligere har tenkt, og en bedring av rekruttering og reduksjon av frafall må være mangefasettert. Våre data tyder på at det ikke er ett enkelttiltak som kan bedre situasjonen, men mange tiltak, sier hun.

Likevel mener ikke Birkeli at det er helt bekmørkt.

- Rekrutteringspotensialet er der. Det må «bare» hentes ut. Vår studie viser at over halvparten av legene enten hadde vurdert allmennmedisin, men valgt det bort eller hadde jobbet i faget, men sluttet. Det er med andre ord interesserte leger der ute. Dataene tyder på at det er viktig å tenke rekruttering helt fra starten, og siden vi også ser i undersøkelsen at «tilfeldigheter» spiller inn, kan det være viktig å motivere studenter tidlig og legge til rette for gode spesialistutdanningsløp.

\section{- Det haster}

Nils Kristian Klev nikker gjenkjennende mens han spiser lunsjen sin. Et intervju og et måltid må slås sammen. Det er hektiske dager for lederen av Allmennlegeforeningen.

- Antallet oppgaver er uhåndterbare. Arbeidstimene øker massivt. Reallønnen viser nedgang. Den totale arbeidsmengden er for stor, og kombinasjon av hjem og arbeid oppleves umulig. Rekrutteringspotensialet i vår undersøkelse fra Ernst \& Young viser enda færre reelle fastlegekandidater - kun $9 \%$ med studenter og LIS1-leger. Men dersom 
rammevilkårene hadde vært riktige, viser undersøkelsen at hele 30 \% egentlig er interessert i allmennmedisin og kunne tenkt seg en karriere innen faget. I tillegg viser undersøkelsen at hele $75 \%$ faktisk synes allmennmedisin er spennende.

Han puster nesten ikke. Klev kan det på rams. Alle argumentene. Alle faktaene. Foreningen har ropt i ti år. Varslet krisen. Stått i alle de negative medieoppslagene.

- Jeg aner en viss motvilje mot enda flere reportasjer og artikler om fastlegekrisen blant dem som faktisk holder ut og står i tilværelsen på daglig basis?

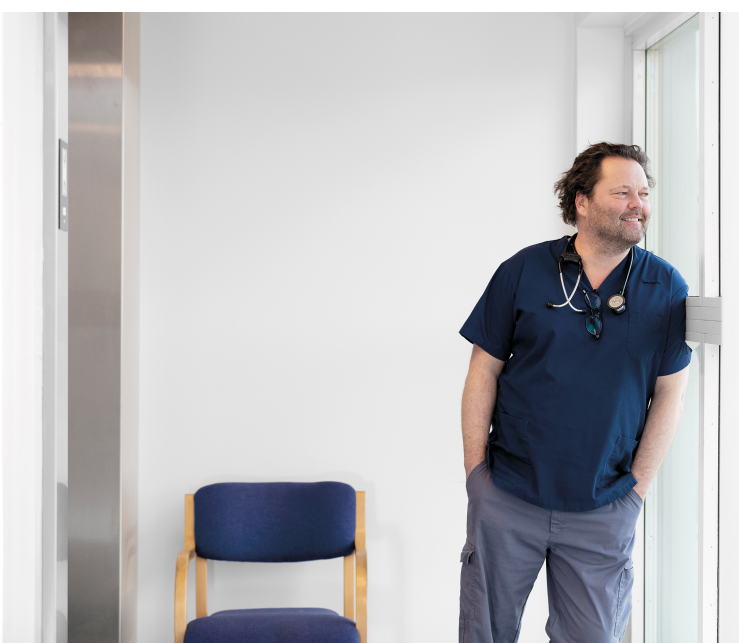

Christian Askenberg, spesialist i plastikkirurgi, gikk fra verdenen på sykehuset til tilvcerelsen som fastlegevikar- og trives. Foto: Christian Tunge

- Du har rett. Men vi har vært helt avhengige av at noe gjøres. Det er en hårfin balanse. Man må etablere en kriseforståelse. Det siste året føler jeg at politikerne har tatt det innover seg. Nå er det et være eller ikke-være for fastlegeordningen. Alt faller på handlingsplanen. Og forhåpentligvis kan vi begynne å snu pessimismen til noe positivt.

Han sier at fastlegeordningen må stabiliseres i første omgang. De økonomiske ressursene må økes for å klare å beholde dagens fastleger. Deretter må rekrutteringen få fart på seg. Og det haster.

- Vi er positive. Løsningen er like enkel som den er vanskelig. Vi trenger flere allmennleger, og vi må gjøre arbeidshverdagen for fastlegene mer attraktiv. Fastlegeordningen har vist seg som en suksess. Det vil være fatalt å ødelegge noe som har fungert så godt.

Han forteller at hovedmodellen som Allmennlegeforeningen fortsatt ønsker, er næringsmodellen, men at det også bør tilrettelegges for alternativer som fastlønn eller blandingsmodeller - slik at personer som Marte Skogen Evje og andre unge i etableringsfasen kan få seg arbeid med trygge rammer. Kanskje vil de senere gå over til en næringsmodell dersom det frister.

- Å drive fastlegekontor har jo egentlig vært veldig attraktivt på grunn av autonomien. Men det har blitt for mange oppgaver og for lange arbeidsdager uten tilstrekkelig tilførsel av ressurser. Vi vet at fastlønnsalternativet er betydelig dyrere for kommunen. Hvis vi derfor bedrer rammebetingelsene også for selvstendig næringsdrivende, kan vi øke attraktiviteten for flere grupper.

Han forteller at kommuner rapporterer at de får mange flere søkere til fastlønnsstillinger enn til åpne fastlegehjemler.

- Ofte får de ingen søkere. Det er et tydelig symptom.

\section{Fra sykehus til fastlege}

Og for alle som er lei av det negative fokuset: Her kommer en gladhistorie om kjerringa eller gubben - mot strømmen, Christian Askenberg.

«Avh, glemte dette. Er hjemme. Kommer nå er der 3 min over». 
Meldingen tikker inn på mobilen på venteværelset til Berg Legekontor. Han løp visst hjemom i lunsjen, Christian Askenberg, og glemte avtalen. Litt stresset er han visst.

To minutter over hel kommer han løpende inn med en pizzaeske i hånden.

- Beklager. Vi holder på med noe oppussing hjemme og jeg løp for å fikse noe der mens jeg skulle spise lunsj. Vil du ha pizza?

- Du er stresset på grunn av oppussing, altså, ikke fordi det er for mye på jobb?

- Nei, nei. Jeg synes ikke jobben er så stressende.

Askenberg er spesialist i plastikkirurgi og har jobbet i 20 år på sykehus med kirurgiske fag.

- Det var mye tung vaktbelastning og mye jobbing i helger og i høytider. Også fikk jeg barn sent $\mathrm{i}$ livet, og jeg nærmer meg 50 år. Det var mye det som var bakgrunnen for at jeg ønsket meg noe der jeg kunne kombinere hjem og arbeid bedre, sier han, mens han sluker pizzaen inne på personalrommet.

Han forteller at mens han jobbet på Oslo universitetssykehus var det mye endringer.

- Jeg synes egentlig at hver gang det har blitt endringer, så har det blitt litt dårligere for hver gang - både for pasientene og for dem som jobber der. Så jeg følte egentlig at det gikk feil vei. Da ble jeg rett og slett lei.

Hele yrkeskarrieren har Askenberg kjørt legevakt i tillegg til arbeidet på sykehuset. Han føler han har hatt allmennmedisinen med seg hele tiden - kanskje mer enn kirurger flest.

- Det er noen år siden jeg begynte å leke med tanken på å gå over til allmennmedisin. Det var imidlertid tilfeldig at jeg kom over en stillingsannonse som vikar for hun som har fastlegehjemmelen her. Stillingen var altså her, og jeg bor rett borti gata. Og da tenkte jeg: «Ok, nå prøver jeg!»

I nesten et år har han jobbet som fastlegevikar i Nordre Aker bydel.

- Jeg synes egentlig det har gått veldig bra. Jeg trives kjempegodt. Men, det skal sies, det er forskjell på legekontorer. Listene er ulike. På min er det få med rusproblemer, egentlig nesten ingen, og lite sosiale problemer. Det er god levestandard i området. Jeg slipper de veldig tunge pasientene, som det er mye papirarbeid med. Da jeg tok over, ba jeg om å øke listen slik at den ble full, for jeg følte jeg hadde kapasitet til det, sier han, og kaster en brannfakkel:

- Jeg kjenner meg ikke helt igjen i bildet som er dannet av fastlegekrisen. Jeg føler ikke at arbeidsbyrden er så voldsom. Jeg synes ikke den er uoverkommelig i det hele tatt. Men jeg er vant til å jobbe mye og vant til lange dager fra før.

Han ser likevel utfordringene med økonomien og savner konstruktive endringer på det området.

- Jeg jobber også veldig mye gratis. Det er jo ikke akkurat attraktivt. Jeg er likevel heldig som har en kone som ikke jobber skift, men har en trygg jobb og kan være hjemme med barna når de syke. Det er ganske vanskelig å være hjemme med barna når man ikke får noen penger og pasientene dine ikke får noen time. Det kjenner jeg litt på.

Han poengterer at han godt forstår at for unge, som er i en etableringsfase, som er ferdig med studier og skal kjøpe seg bolig og få barn, så er fastlegeordningen ganske lite fristende i stedet for en fast jobb på sykehuset.

- Du er fornøyd, men tror du at du arbeider i en litt beskyttet tilværelse her oppe i Nordre Aker?

- Jeg tror jeg har en beskyttet tilværelse her, og jeg tror nok at mange av dem som går kraftig ut, har vært leger i allmennfaget i mange flere år enn meg. Jeg tror at de tydelig ser at det går helt feil vei, og at det blir vanskeligere å jobbe som fastlege uten å jobbe veldig, veldig mye. Men jeg er liksom så fornøyd, og vil fortsette med dette. Jeg trives med faget, jeg trives med fleksibiliteten, og jeg kan velge å være sammen med barna mine på kvelder og i helger. Det 
er mye verdt for meg.

Publisert: 30. mars 2020. Tidsskr Nor Legeforen. DOI: 10.4045/tidsskr.20.0197

(C) Tidsskrift for Den norske legeforening 2020. Lastet ned fra tidsskriftet.no 